\title{
PENGARUH MOTIVASI DAN KOMPENSASI TERHADAP PRODUKTIVITAS KARYAWAN PADA PT. HADI PRIMA TEKNIK ALAM SUTERA - KOTA TANGERANG
}

\author{
Muhammad Gandung ${ }^{1,}$ Suwanto ${ }^{2}$ \\ Fakultas Ekonomi, Universitas Pamulang \\ Email: dosen02020@unpam.ac.id ${ }^{1}$,dosen01813@unpam.ac.id²
}

\begin{abstract}
Purpose. This study aims to determine the motivation and compensation for employee productivity at PT Hadi Prima Teknik Alam Sutera Kota Tangerang.

Methods. The research method used in this study is an associative method and data collection using a questionnaire technique. This study used a saturated sample with 60 respondents. The method of data analysis was the validity test, the reliability test, the multiple linear regression equation, the correlation coefficient, the coefficient of determination, and the significance test.
\end{abstract}

Findings. The results showed multiple correlation $=0.844$, meaning that motivation and compensation had a very strong relationship with employee productivity. In the multiple linear regression equation, you get $Y=5.828+0.301 X 1+0.564 X 2$, which means that if the $X 1$ variable is increased by 1 unit, then the $Y$ variable increases by 0.301 units at a constant of 5.828, and if the X2 variable is increased by 1 unit, then the $Y$ variable increases by 0.564 units at the constant 5,828. The coefficient of determination of $71.3 \%$ indicates that the contribution of independent variables (motivation and compensation) in an effort to increase employee productivity, while the remaining $28.7 \%$ is influenced by other factors not examined in this study. After testing the hypothesis, there is a simultaneous significant influence between motivation and compensation on employee productivity at PT Hadi Prima Teknik, this can be seen from F count> Ftable or 70.680>2.770.

Implication. Companies should always pay attention and provide motivation and compensation for the welfare that should be given to employees. namely by providing training, career development, appreciation, rewards that are able to support every employee who works to be more enthusiastic.

Keywords. Motivation, Compensation and Productivity.

\begin{abstract}
ABSTRAK
Tujuan. Penelitian ini bertujuan untuk mengetahui motivasi dan kompensasi terhadap produktivitas karyawan pada PT Hadi Prima Teknik Alam Sutera Kota Tangerang.

Metode. Metode penelitian yang dipergunakan dalam penelitian ini adalah metode asosiatif dan pengumpulan data dengan teknik kuesioner. Penelitian ini menggunakan sampel jenuh dengan responden sebanyak 60. Metode analisis data dengan uji validitas, uji reliabilitas, persamaan regresi linier berganda, koefisien kolerasi, koefisien determinasi, dan uji signifikansi.

Hasil. Hasil penelitian menunjukkan korelasi berganda $=0,844$ artinya motivasi dan kompensasi mempunyai tingkat hubungan yang sangat kuat terhadap produktivitas karyawan. Dalam persamaan regresi linier berganda di dapat $\mathrm{Y}=5,828+0,301 \mathrm{X}_{1}+$
\end{abstract}


$0,564 \mathrm{X}_{2}$ yang artinya apabila variabel $\mathrm{X}_{1}$ dinaikan 1 satuan, maka variabel $\mathrm{Y}$ naik sebesar 0,301 satuan pada konstanta 5,828, dan apabila variabel $\mathrm{X}_{2}$ dinaikan 1 satuan, maka variabel Y naik sebesar 0,564 satuan pada konstanta 5,828. Nilai Koefisien determinasi sebesar 71,3 \% menunjukan bahwa besarnya kontribusi dari variabel bebas (motivasi dan kompensasi) dalam upaya meningkatkan produktivitas karyawan, sedangkan sisanya 28,7 $\%$ dipengaruhi oleh faktor lain yang tidak diteliti dalam penelitian ini. Setelah dilakukan uji hipotesis, secara simultan terdapat pengaruh yang signifikan antara motivasi dan kompensasi terhadap produktivitas karyawan pada PT Hadi Prima Teknik, hal ini terlihat dari $\mathrm{F}_{\text {hitung }}>\mathrm{F}_{\text {tabel }}$ atau 70,680 $>2,770$.

Implikasi. Perusahaan hendaknya selalu memperhatikan dan memberikan motivasi serta kompensasi untuk kesejahteraan yang seharusnya diberikan kepada karyawan. yaitu dengan cara memberikan pelatihan, pengembangan karier, apresiasi, rewards yang mampu menunjang agar setiap karyawan yang bekerja manjadi lebih bersemangat.

Kata Kunci. Motivasi, Kompensasi dan Produktivitas.

\section{Pendahuluan}

Manajemen sumber daya manusia mengganggap bahwa karyawan adalah kekayaan utama sebuah organisasi atau perusahaan yang harus dikelola dengan baik karena keberadaan manajemen sumber daya manusia sangat penting dalam mengelola, mengatur, dan mengurus sebuah perusahaan. Peranan sumber daya (tenaga kerja) yang dimiliki oleh individu dapat digunakan secara maksimal sehingga tercapai tujuan bersama perusahaan. Setiap perusahaan berupaya untuk memiliki karyawan yang berperan aktif sehingga dapat menghasilkan produktivitas yang baik dan memberikan kontribusi pada pencapaian target yang telah ditetapkan oleh perusahaan. Perkembangan penggunaan batubara didunia sebagai energi dimulai sejak revolusi industri di Eropa (abad 19), yaitu untuk menggerakkan lokomotif dan mesin-mesin uap sehingga disebut zaman keemasan batubara.

Batubara bahan bakar fosil adalah sumber energi terpenting untuk pembangkitan listrik dan berfungsi sebagai bahan bakar. Begitu halnya dengan PT Hadi Prima Teknik anak cabang dari PT. Sadikun Niagamas Raya Perusahaan yang bergerak dibidang batubara ini dikembangkan untuk memperluas jaringan, menjangkau pasar-pasar potensial serta kesiapan dalam menghadapi era globalisasi. PT HADI PRIMA TEKNIK menjadi trader penjualan produk batu bara, jalur PT Hadi Prima Teknik mencakup skala nasional dan diorganisir melalui bisnis unit yang telah tersebar.

Berdasarkan kemauan dan kompetensi individu merupakan bagian terpenting dari upaya pemberian pemenuhan kebutuhan bagi karyawan, terutama pada upaya memupuk motivasi kerja karyawan kearah produktivitas yang lebih tinggi, sebab dengan adanya pemenuhan kebutuhan yang sesuai dengan harapan karyawan, terutama imbalan finansial berupa gaji dan bonus atas prestasi mereka, maka memungkinkan karyawan berkonsentrasi penuh terhadap pekerjaannya dan secara langsung akan berdampak positif bagi perusahaan tersebut.

Tabel 1. Motivasi Karyawan pada PT Hadi Prima Teknik Kota Tangerang

\begin{tabular}{|c|c|c|c|c|}
\hline No & Indikator Motivasi & 2017 & 2018 & 2019 \\
\hline 1 & Kebutuhan fisiologis & $20 \%$ & $15 \%$ & $15 \%$ \\
\hline 2 & Kebutuhan rasa aman & $15 \%$ & $15 \%$ & $10 \%$ \\
\hline 3 & Kebutuhan sosial & $10 \%$ & $10 \%$ & $10 \%$ \\
\hline 4 & Kebutuhan penghargaan & $15 \%$ & $10 \%$ & $10 \%$ \\
\hline 5 & Kebutuhan aktualisasi diri & $15 \%$ & $10 \%$ & $10 \%$ \\
\hline & Jumlah persentase & $75 \%$ & $60 \%$ & $55 \%$ \\
\hline
\end{tabular}

Sumber : PT Hadi Prima Teknik (2020) 
Dari tabel diatas motivasi karyawan PT Hadi Prima Teknik dari mulai kebutuhan fisiologis dalam perusahaan yaitu kebutuhan dasar akan makan, minum dan hal yang berkaitan dengan kebutuhan dasar yang pada dasarnya berkaitan dengan gaji. kebutuhan rasa aman disini lingkungan kerja yang aman, bersih, dan lebih jauh lagi terdapat jaminan pasca pensiun sehingga merasa aman secara finansial. Kebutuhan sosial yaitu menjalin persahabatan dengan rekan sekerja, satu tim dan interaksi antara atasan dan bawahan. Kebutuhan penghargaan adalah terkait dengan jabatan yang lebih tinggi, mempromosikan bawahannya ke posisi yang lebih tinggi. Kemudian kebutuhan aktualisasi diri dengan Kreatifitas dan ketrampilan akan selalu dilatih serta terus berkembang.

Pada tahun 2017 dapat diketahui data dengan penilaian baik yaitu 75\%. Pada tahun 2018 yaitu menjadi 60\%, dan pada tahun 2019 yaitu 55\%. Jadi kesimpulannya para karyawan bisa bekerja dengan baik dan berkualitas dengan adanya dorongan dari atasan untuk tetap bekerja sesuai prosedur perusahaan. Dan apabila karyawan bekerja dengan daya pendorong dari atasan mungkin karyawan akan merasa bahwa dirinya sangat penting bagi perusahaan karena karyawan bukan hanya pekerja tapi juga sebagai asset perusahaan agar perusahaan dapat lebih berkembang dan bisa lebih maju. Dan untuk karyawan pun harus memiliki kerelaan dalam melaksanakan pekerjaannya.

Kompensasi sangat penting bagi karyawan, karena besarnya kompensasi merupakan pencerminan atau ukuran nilai pekerjaan karyawan itu sendiri. Sebaliknya besar kecilnya kompensasi dapat mempengaruhi motivasi dan produktivitas pada karyawan. Maka dari itu pentingnya kompensasi maka perusahaan akan mendapatkan keuntungan yang diharapkan dan karyawan juga mendapatkan hasilnya. Seperti halnya pada PT Hadi Prima Teknik, dalam pemberian kompensasi kepada karyawan masih belum terlaksana dengan baik, karena masih kurang optimal dalam pemberian secara layak sehingga mengakibatkan karyawan mengalami penurunan dalam produktivitasnya akibat ketidaksesuaian pemberian kompensasi. Masalah yang timbul adalah ketidaksesuaian dengan pekerjaan yang dilakukan, pemberian kompensasi berupa insentif masih belum sesuai dengan banyaknya pekerjaan yang dijalankan.

Tabel 2. Pemberian Insentif Pada PT Hadi Prima Teknik

\begin{tabular}{|c|c|c|c|c|}
\hline \multirow{2}{*}{ Golongan } & \multirow{2}{*}{ Masa Kerja } & \multicolumn{2}{|c|}{ Besarnya Insentif } & \multirow{2}{*}{ Keterangan } \\
\cline { 3 - 4 } & & Ideal & Riil & \\
\hline Pimpinan & $<2$ Tahun & $5 \%$ & $4 \%$ & Kurang sesuai \\
Keuangan & $<2$ Tahun & $4 \%$ & $3 \%$ & Kurang sesuai \\
Personalia & $<2$ Tahun & $3 \%$ & $2 \%$ & Kurang sesuai \\
Administrasi & $<2$ Tahun & $2 \%$ & $1 \%$ & Kurang sesuai \\
Operasional & $<2$ Tahun & $1,5 \%$ & $0.5 \%$ & Kurang sesuai \\
\hline
\end{tabular}

Sumber : PT Hadi Prima Teknik (2020)

Berdasarkan tabel data diatas dapat dilihat bahwa besarnya insentif yang di terima pegawai operasional sampai tahap pimpinan masih rendah. Mulai dari pimpinan idealnya $5 \%$ tetapi hanya mendapatkan $4 \%$, begitupun bagian keuangan ideal $4 \%$ namun yang didapatkan $3 \%$, personalia dengan ideal $3 \%$ hanya mendapatkan $2 \%$, serta bagian administrasi dari $2 \%$ hanya mendapat $1 \%$. Dan pada bagian operasional dengan ideal $1.5 \%$ hanya mendapatkan 0.5\%. Dengan perhitungan dari laba bersih perusahaan yang didapatkan selama tahun 2018.

Hal ini menunjukan bahwa pemberian insentif terhadap karyawan masih belum sesuai dengan standar yang sudah ditentukan. Maka hal ini mempengaruhi produktivitas karyawan menurun. Salah satu upaya perusahaan untuk mewujudkan tujuan perusahaan adalah dengan 
cara mempunyai karyawan yang memiliki produktivitas yang baik dan terus mengalami kemajuan setiap tahunnya. Dengan memberikan hasil kerja yang optimal bagi perusahaan.

Tabel 3. Data Produktivitas Hasil Penjualan Karyawan Pada PT HADI PRIMA TEKNIK Tahun 2016-2018

\begin{tabular}{|c|c|c|c|c|c|}
\hline No & Tahun & Target (MT) & Realisasi (MT) & $\mathbf{( \% )}$ & Keterangan \\
\hline 1 & 2016 & $50.000 .000 \mathrm{MT}$ & $47.210 .000 \mathrm{MT}$ & $94,42 \%$ & Tidak Target \\
\hline 2 & 2017 & $50.000 .000 \mathrm{MT}$ & $44.155 .000 \mathrm{MT}$ & $88,31 \%$ & Tidak Target \\
\hline 3 & 2018 & $50.000 .000 \mathrm{MT}$ & $39.135 .000 \mathrm{MT}$ & $78,27 \%$ & Tidak Target \\
\hline
\end{tabular}

Sumber : PT Hadi Prima Teknik (2020)

Berdasarkan tabel diatas target penjualan pada PT HADI PRIMA TEKNIK pada tahun 2016 sampai dengan 2018 tidak stabil dan tidak memenuhi target yang telah ditetapkan perusahaan, tentunya hal ini berpengaruh pada realisasi pendapatan perbulan, dan terjadinya penurunan produktivitas karyawan pada PT HADI PRIMA TEKNIK. Dengan kata lain penjualan batubara tidak selalu mencapai target penjualan.

Dengan demikian dapat di simpulkan bahwa pentingnya produktivitas terhadap kelangsungan tujuan perusahaan dengan saling memberikan timbal balik antara karyawan dengan perusahaan. Banyak akibat yang merugikan suatu perusahaan yang di sebabkan karyawan tidak memiliki produktivitas yang tinggi akibatnya dapat terjadi berbagai bentuk tindakan atau perbuatan yang merugikan perusahaan, sebagai contoh hasil kerja yang tidak memenuhi syarat-syarat yang di tetapkan, dan tidak terpenuhi target yang di tetapkan perusahaan.

Berkaitan dengan hal tersebut, maka setiap organisasi maupun perusahaan akan selalu berusaha untuk meningkatkan produktivitas kerja karyawan, dengan harapan apa yang menjadi tujuan organisasi akan tercapai. Berbagai cara akan di tempuh dalam peningkatan produktivitas karyawan. Oleh sebab itu penelitian ini dilakukan untuk meneliti lebih lanjut tentang "Pengaruh Motivasi dan Kompensasi Terhadap Produktivitas Karyawan Pada PT Hadi Prima Teknik, Alam Sutera - Kota Tangerang".

\section{Kajian Pustaka dan Hipotesis}

Motivasi. Motivasi ditinjau dari ilmu manajemen merupakan suatu fungsi atau alat yang erat kaitannya dengan manusia sebagai penggerak orang-orang agar mampu melakukan kegiatankegiatan organisasi. Bagi pimpinan organisasi kegiatan manajemen penting dalam meningkatkan produktivitas organisasi. Menurut Sutrisno (dalam Hadi, 2019:216) berpendapat bahwa Motivasi adalah suatu faktor yang mendorong seseorang untuk melakukan aktivitas tertentu, oleh karena itu motivasi sering kali diartikan pula sebagai faktor pendorong perilaku seseorang.

H. Motivasi berpengaruh signifikan terhadap produktivitas karyawan

Kompensasi. Menurut Larasati (2018:89) kompensasi merupakan salah satu faktor baik secara langsung atau tidak langsung mempengaruhi tinggi rendahnya kinerja karyawan oleh karena itu sudah semestinya pemberian kompensasi kepada karyawan perlu mendapat perhatian khusus dari pihak manajemen agar motivasi karyawan dapat dipertahankan dan kinerja karyawan akan terus meningkat.

Pembentukan sistem kompensasi yang efektif merupakan bagian penting dari manajemen sumber daya manusia karena membantu menarik dan mempertahankan pekerjapekerja yang berbakat. Selain itu sistem kompensasi perusahaan memiliki dampak terhadap kinerja strategis. Sistem imbalan mencakup gaji, penghasilan, uang pensiun, uang liburan, promosi ke posisi yang lebih tinggi (berupa gaji dan keuntungan yang lebih tinggi). Juga 
berupa asuransi keselamatan kerja, transfer secara horizontal untuk mendapat posisi yang lebih menantang atau ke posisi utama untuk pertumbuhan dan pengembangan berikutnya, secara berbagai macam bentuk pelayanan. Pekerja sebagai manusia memiliki kebutuhankebutuhan dan akan selalu berusaha memenuhi kebutuhannya, maka itulah manusia bekerja dengan harapan untuk mendapatkan imbalan/Kompensasi.

$\mathbf{H}_{2}$. Kompensasi berpengaruh signifikan terhadap produktivitas karyawan

Produktivitas. Secara teknis produktivitas merupakan perbandingan antara hasil yang dicapai dengan pasar tenaga kerja persatuan waktu dan sebagai tolak ukur jika ekspansi dan aktivitas dari sikap sumber yang digunakan selama produktivitas berlangsung dengan membandingkan jumlah yang dihasilkan dengan setiap sumber yang digunakan.

Sunyoto (dalam Weni, 2018:139) produktivitas kerja adalah sikap mental yang selalu berusaha dan mempunyai pandangan suatu kebutuhan hari ini lebih besar dari kehidupan hari kemarin, dan berbeda pula dengan kehidupan pada masa yang akan datang. Produktivitas kerja merupakan perbandingan antara hasil kerja yang dicapai (output) dengan keseluruhan sumber daya yang digunakan (input) dari tenaga kerja.

$\mathbf{H}_{3}$. Motivasi dan Kompensasi berpengaruh signifikan terhadap produktivitas karyawan

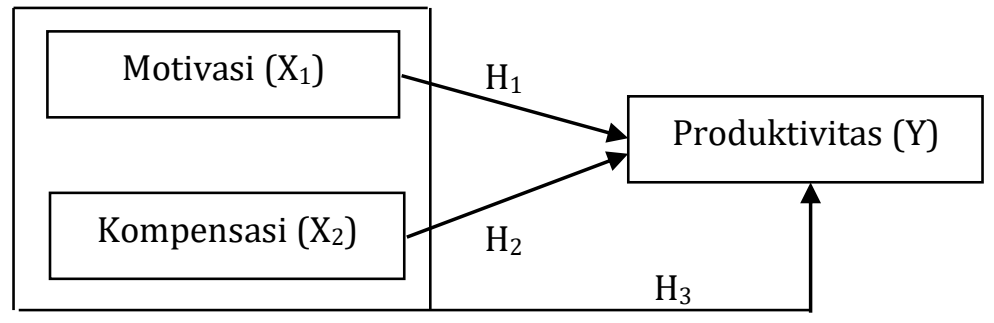

Gambar 1. Model Penelitian

\section{Metode Penelitian}

Jenis penelitian ini adalah asosiatif, menurut Sugiyono (2017:44) yaitu "Penelitian yang bertujuan untuk mengetahui pengaruh atau hubungan antara dua variabel atau lebih". Dengan demikian penelitian asosiatif ini dapat dibangun suatu teori yang berfungsi untuk menjelaskan, meramalkan dan mengontrol suatu gejala. Dalam penelitian populasinya adalah karyawan PT HADI PRIMA TEKNIK. Sementara sampel yang digunakan adalah seluruh karyawan PT HADI PRIMA TEKNIK yang berjumlah 60 karyawan.

\section{Uji Instrumen Penelitian}

Dalam suatu penelitian, data mempunyai kedudukan yang sangat penting. Hal ini dikarenakan data merupakan penggambaran variabel yang diteliti dan berfungsi sebagai alat pembuktian hipotesis. Valid atau tidaknya data sangat menentukan kualitas dari data tersebut. Hal ini tergantung instrumen yang digunakan apakah sudah memenuhi asas validitas dan reliabilitas. Adapun dalam pengujian instrumen ini digunakan 2 (dua) pengujian yaitu validitas dan reliabilitas.

\section{Uji Asumsi Klasik}

Uji asumsi klasik digunakan untuk mengetahui ketepatan sebuah data. Menurut Santoso (2015:342) berpendapat "Sebuah model regresi akan digunakan untuk melakukan peramalan sebuah model yang baik adalah model dengan kesalahan peramalan yang seminimal mungkin. Karena itu, sebuah model sebelum digunakan seharusnya memenuhi beberapa asumsi, yang biasa disebut asumsi klasik". Dalam penelitian ini uji asumsi klasik yang digunakan: Uji Normalitas, Uji Multikolinearitas, Uji Autokorelasi, dan Uji Heterokedastisitas. 


\section{Analisis Kuantitatif}

Analisis kuantitatif adalah penelitian untuk menilai kondisi dari nilai pengaruh, dan signifikansi pengaruh tersebut. Dalam penelitian ini analisis kuantitatif yang digunakan: Analisis Regresi Linier Sederhana, Linier Berganda, Analisis Koefisien Korelasi, Analisis Koefisien Determinasi, Pengujian Hipotesis.

\section{Hasil Penelitian dan Pembahasan}

\section{Uji Validitas Instrumen}

Tabel 4. Hasil Uji Validitas Berdasarkan Variabel Motivasi $\left(\mathrm{X}_{1}\right)$

\begin{tabular}{|c|c|c|c|c|}
\hline \multicolumn{2}{|r|}{ Item Kuesioner } & r hitung & r tabel & Keputusan \\
\hline & $\begin{array}{l}\text { 1. Indikator : Kebutuhan } \\
\text { Fisiologis }\end{array}$ & \multirow[t]{2}{*}{0,384} & \multirow[t]{2}{*}{0.256} & \multirow[t]{2}{*}{ Valid } \\
\hline 1. & Pernyataan & & & \\
\hline \multirow[t]{2}{*}{2.} & Pernyataan & 0,436 & 0.256 & Valid \\
\hline & $\begin{array}{l}\text { 2. Indikator : Kebutuhan Rasa } \\
\text { Aman }\end{array}$ & \multirow[t]{2}{*}{0,374} & \multirow[t]{2}{*}{0.256} & \multirow[t]{2}{*}{ Valid } \\
\hline 3. & Pernyataan & & & \\
\hline \multirow[t]{2}{*}{4.} & Pernyataan & 0,531 & 0.256 & Valid \\
\hline & $\begin{array}{l}\text { 3. Indikator: Kebutuhan } \\
\text { Sosial }\end{array}$ & \multirow[t]{2}{*}{0,695} & \multirow[t]{2}{*}{0.256} & \multirow[t]{2}{*}{ Valid } \\
\hline 5. & Pernyataan & & & \\
\hline \multirow[t]{2}{*}{6.} & Pernyataan & 0,528 & 0.256 & Valid \\
\hline & $\begin{array}{l}\text { 4. Indikator: Kebutuhan } \\
\text { Penghargaan }\end{array}$ & \multirow[t]{2}{*}{0,681} & \multirow[t]{2}{*}{0.256} & \multirow[t]{2}{*}{ Valid } \\
\hline 7. & Pernyataan & & & \\
\hline \multirow[t]{2}{*}{8.} & Pernyataan & 0,729 & 0.256 & Valid \\
\hline & $\begin{array}{l}\text { 5. Indikator : Kebutuhan } \\
\text { Aktualisasi Diri }\end{array}$ & \multirow[t]{2}{*}{0,613} & \multirow[t]{2}{*}{0.256} & \multirow[t]{2}{*}{ Valid } \\
\hline 9. & Pernyataan & & & \\
\hline 10 & Pernyataan & 0,393 & 0.256 & Valid \\
\hline
\end{tabular}

Sumber : Data diolah (2020)

Tabel 5. Hasil Uji Validitas Berdasarkan Variabel Kompensasi $\left(\mathrm{X}_{2}\right)$

\begin{tabular}{|c|c|c|c|c|}
\hline \multicolumn{2}{|r|}{ Item Kuesioner } & $r$ hitung & $r$ tabel & Keputusan \\
\hline & 1. Indikator : Gaji & \multirow{2}{*}{0,631} & \multirow{2}{*}{0.256} & \multirow{2}{*}{ Valid } \\
\hline 1. & Pernyataan & & & \\
\hline 2. & Pernyataan & 0,525 & 0.256 & Valid \\
\hline & 2. Indikator : Upah & \multirow{2}{*}{0,459} & \multirow{2}{*}{0.256} & \multirow{2}{*}{ Valid } \\
\hline 3. & Pernyataan & & & \\
\hline 4. & Pernyataan & 0,586 & 0.256 & Valid \\
\hline & 3. Indikator : Insentif & \multirow{2}{*}{0,535} & \multirow{2}{*}{0.256} & \multirow{2}{*}{ Valid } \\
\hline 5. & Pernyataan & & & \\
\hline 6. & Pernyataan & 0,299 & 0.256 & Valid \\
\hline & 4. Indikator: Benefit & \multirow{2}{*}{0,607} & \multirow{2}{*}{0.256} & \multirow{2}{*}{ Valid } \\
\hline 7. & Pernyataan & & & \\
\hline 8. & Pernyataan & 0,517 & 0.256 & Valid \\
\hline & 5. Indikator : Service & \multirow{2}{*}{0,653} & \multirow{2}{*}{0.256} & \multirow{2}{*}{ Valid } \\
\hline 9. & Pernyataan & & & \\
\hline 10. & Pernyataan & 0,568 & 0.256 & Valid \\
\hline
\end{tabular}

Sumber : Data diolah (2020) 
Tabel 6. Hasil Uji Validitas Berdasarkan Variabel Produktivitas (Y)

\begin{tabular}{|c|c|c|c|c|}
\hline \multicolumn{2}{|r|}{ Item Kuesioner } & r hitung & r tabel & Keputusan \\
\hline & 1. Indikator Target & \multirow{2}{*}{0,466} & \multirow{2}{*}{0.256} & \multirow{2}{*}{ Valid } \\
\hline 1. & Pernyataan & & & \\
\hline 2. & Pernyataan & 0,537 & 0.256 & Valid \\
\hline & 2. Indikator Disiplin & \multirow{2}{*}{0,481} & \multirow{2}{*}{0.256} & \multirow{2}{*}{ Valid } \\
\hline 3. & Pernyataan & & & \\
\hline 4. & Pernyataan & 0,487 & 0.256 & Valid \\
\hline & 3. Indikator Tanggung Jawab & \multirow{2}{*}{0,483} & \multirow{2}{*}{0.256} & \multirow{2}{*}{ Valid } \\
\hline 5. & $\begin{array}{l}\text { Pernyataan } \\
\end{array}$ & & & \\
\hline 6. & Pernyataan & 0,324 & 0.256 & Valid \\
\hline & 4. Indikator Pendidikan & \multirow[b]{2}{*}{0,755} & \multirow{2}{*}{0.256} & \multirow[b]{2}{*}{ Valid } \\
\hline 7. & Pernyataan & & & \\
\hline 8. & Pernyataan & 0,587 & 0.256 & Valid \\
\hline & $\begin{array}{l}\text { 5. Indikator Kerjasama } \\
\text { /Teamwork }\end{array}$ & \multirow[t]{2}{*}{0,588} & \multirow[t]{2}{*}{0.256} & \multirow[t]{2}{*}{ Valid } \\
\hline 9. & $\begin{array}{c}\text { Pernyataan } \\
\end{array}$ & & & \\
\hline & 6. Indikator Prosedur Kerja & \multirow{2}{*}{0,578} & \multirow{2}{*}{0.256} & \multirow{2}{*}{ Valid } \\
\hline 10. & Pernyataan & & & \\
\hline
\end{tabular}

Sumber : Data diolah (2020)

Berdasarkan data tabel di atas, variabel $X_{1}, X_{2}$ dan $Y$ diperoleh nilai $r$ hitung $>r$ tabel (0.254), dengan demikian maka semua item kuesioner dinyatakan valid. Untuk itu kuesioner yang digunakan layak untuk diolah sebagai data penelitian.

\section{Uji Reliabilitas Instrumen}

Tabel 7. Hasil Uji Reliabilitas Variabel Independen dan Dependen

\begin{tabular}{|l|c|c|c|}
\hline \multicolumn{1}{|c|}{ Variabel } & Cronbatch Alpha & $\begin{array}{c}\text { Standar Cronbatch } \\
\text { Alpha }\end{array}$ & Keputusan \\
\hline Motivasi (X1) & 0.723 & 0.600 & Reliabel \\
\hline Kompensasi (X2) & 0.725 & 0.600 & Reliabel \\
\hline Produktivitas karyawan (Y) & 0.712 & 0.600 & Reliabel \\
\hline
\end{tabular}

Sumber : Data diolah (2020)

Berdasarkan hasil pengujian pada tabel di atas, menunjukkan bahwa variabel motivasi $\left(\mathrm{X}_{1}\right)$, kompensasi $\left(\mathrm{X}_{2}\right)$ dan produktivitas karyawan $(\mathrm{Y})$ dinyatakan reliabel, hal itu dibuktikan dengan masing-masing variabel memiliki nilai Chronbath Alpha lebih besar dari 0,600.

\section{Pengujian Asumsi Klasik (Uji Prasyarat Data)}

\section{Uji Normalitas}

Tabel 8. Hasil Uji Normalitas Dengan Kolmogorov-Smirnov Test

\begin{tabular}{|l|c|c|c|c|c|c|}
\hline \multicolumn{7}{|c|}{ Tests of Normality } \\
\hline & \multicolumn{2}{|c|}{ Kolmogorov-Smirnov } & \multicolumn{3}{c|}{ Shapiro-Wilk } \\
\cline { 2 - 7 } & Statistic & df & Sig. & Statistic & df & Sig. \\
\hline $\begin{array}{l}\text { Produktivitas } \\
\text { Karyawan (Y) }\end{array}$ & .105 & 60 & .098 & .979 & 60 & .371 \\
\hline
\end{tabular}

Sumber : Data diolah (2020)

Berdasarkan hasil pengujian pada tabel di atas, diperoleh nilai signifikansi $\alpha=0,098$ dimana nilai tersebut lebih besar dari nilai $\alpha=0,050$ atau $(0,098>0,050)$. Dengan demikian maka asumsi distribusi persamaan pada uji ini adalah normal. 


\section{Uji Multikolinearitas}

Tabel 9. Hasil Pengujian Multikolinearitas Dengan Collinearity Statistic Produktivitas karyawan Sebagai Variabel Dependen

\begin{tabular}{|c|c|c|}
\hline \multirow{2}{*}{ Variabel } & \multicolumn{2}{|c|}{ Colinerity Statistics } \\
\cline { 2 - 3 } & Tolerance & VIF \\
\hline Motivasi $\left(\mathrm{X}_{1}\right)$ & 0.693 & 1.444 \\
\hline Kompensasi $\left(\mathrm{X}_{2}\right)$ & 0.693 & 1.444 \\
\hline
\end{tabular}

Sumber : Data diolah (2020)

Berdasarkan hasil pengujian multikolinieritas pada tabel di atas diperoleh nilai tolerance masing-masing variabel bebas yaitu motivasi sebesar 0,693 dan kompensasi sebesar 0,693, dimana kedua nilai tersebut kurang dari 1, dan nilai Variance Inflation Factor (VIF) variabel motivasi sebesar 1,444 serta kompensasi sebesar 1,444 dimana nilai tersebut kurang dari 10. Dengan demikian model regresi ini tidak ada multikolinearitas.

\section{Uji Autokorelasi}

Tabel 10. Uji Durbin-Watson

\begin{tabular}{|c|c|c|c|c|c|}
\hline \multicolumn{6}{|c|}{ Model Summaryb } \\
\hline Model & $\mathrm{R}$ & R Square & $\begin{array}{l}\text { Adjusted R } \\
\text { Square }\end{array}$ & $\begin{array}{l}\text { Std. Error of } \\
\text { the Estimate }\end{array}$ & $\begin{array}{l}\text { Durbin- } \\
\text { Watson }\end{array}$ \\
\hline 1 & $.844^{a}$ & .713 & .703 & 1.92101 & 1.822 \\
\hline \multicolumn{6}{|c|}{ a. Predictors: (Constant), Kompensasi (X2), Motivasi (X1) } \\
\hline \multicolumn{6}{|c|}{ b. Dependent Variable: Produktivitas Karyawan (Y) } \\
\hline
\end{tabular}

Berdasarkan hasil pengujian pada tabel di atas, model regresi ini tidak ada autokorelasi, hal ini dibuktikan dengan nilai Durbin-Watson sebesar 1.822 yang berada diantara interval $1.550-2.460$.

\section{Uji Heteroskedastisitas}

Tabel 11. Hasil Pengujian Heteroskesdastisitas Dengan Uji Glejser

\begin{tabular}{|c|c|c|c|c|c|c|}
\hline \multicolumn{7}{|c|}{ Coefficients ${ }^{a}$} \\
\hline \multirow{2}{*}{\multicolumn{2}{|c|}{ Model }} & \multicolumn{2}{|c|}{$\begin{array}{l}\text { Unstandardized } \\
\text { Coefficients }\end{array}$} & \multirow{2}{*}{$\begin{array}{c}\text { Standardized } \\
\text { Coefficients } \\
\text { Beta }\end{array}$} & \multirow[b]{2}{*}{$\mathrm{t}$} & \multirow[b]{2}{*}{ Sig. } \\
\hline & & $\mathrm{B}$ & Std. Error & & & \\
\hline \multirow[t]{3}{*}{1} & (Constant) & .432 & 1.629 & & .265 & .792 \\
\hline & Motivasi (X1) & .039 & .045 & .137 & .867 & .390 \\
\hline & Kompensasi (X2) & -.010 & .045 & -.035 & -.221 & .826 \\
\hline
\end{tabular}

Sumber : Data diolah (2020)

Berdasarkan hasil pengujian pada tabel di atas, glejser test model pada variabel motivasi $\left(\mathrm{X}_{1}\right)$ diperoleh nilai probability signifikansi (Sig.) sebesar 0,390 dan kompensasi $\left(\mathrm{X}_{2}\right)$ diperoleh nilai probability signifikansi (Sig.) sebesar 0,826 dimana keduanya nilai signifikansi (Sig.) > 0,05. Dengan demikian regression model pada data ini tidak ada gangguan heteroskesdastisitas, sehingga model regresi ini layak dipakai sebagai data penelitian. 


\section{Analisis Kuantitatif}

\section{Regresi Linier Sederhana}

Tabel 12. Hasil Pengujian Regresi Linier Sederhana Variabel Motivasi ( $\left.\mathrm{X}_{1}\right)$

Terhadap Produktivitas karyawan (Y)

\begin{tabular}{|c|c|c|c|c|c|c|}
\hline \multicolumn{7}{|c|}{ Coefficients ${ }^{a}$} \\
\hline & \multirow{2}{*}{ Model } & \multicolumn{2}{|c|}{$\begin{array}{l}\text { Unstandardized } \\
\text { Coefficients }\end{array}$} & \multirow{2}{*}{$\begin{array}{c}\begin{array}{c}\text { Standardized } \\
\text { Coefficients }\end{array} \\
\text { Beta }\end{array}$} & \multirow{2}{*}{$\mathrm{t}$} & \multirow{2}{*}{ Sig. } \\
\hline & & B & Std. Error & & & \\
\hline \multirow{2}{*}{1} & (Constant) & 15.741 & 3.398 & & 4.633 & .000 \\
\hline & Motivasi (X1) & .614 & .089 & .670 & 6.880 & .000 \\
\hline
\end{tabular}

Berdasarkan hasil perhitungan regresi pada tabel di atas, maka dapat diperoleh persamaan regresi $\mathrm{Y}=15,741+0,614 \mathrm{X}_{1}$. Dari persamaan di atas maka dapat disimpulkan sebagai berikut:

1. Nilai konstanta sebesar 15,741 diartikan bahwa jika variabel motivasi $\left(\mathrm{X}_{1}\right)$ tidak ada maka telah terdapat nilai produktivitas karyawan $(\mathrm{Y})$ sebesar 15,741 point.

2. Nilai koefisien regresi motivasi $\left(\mathrm{X}_{1}\right)$ sebesar 0,614 diartikan apabila konstanta tetap dan tidak ada perubahan pada variabel kompensasi $\left(\mathrm{X}_{2}\right)$, maka setiap perubahan 1 unit pada variabel motivasi $\left(\mathrm{X}_{1}\right)$ akan mengakibatkan terjadinya perubahan pada produktivitas karyawan (Y) sebesar 0,614 point

Tabel 13. Hasil Pengujian Regresi Linier Sederhana Variabel Kompensasi $\left(\mathrm{X}_{2}\right)$ Terhadap Produktivitas karyawan (Y)

\begin{tabular}{|c|c|c|c|c|c|c|}
\hline \multicolumn{7}{|c|}{ Coefficientsa } \\
\hline \multirow{2}{*}{\multicolumn{2}{|c|}{ Model }} & \multicolumn{2}{|c|}{$\begin{array}{l}\text { Unstandardized } \\
\text { Coefficients }\end{array}$} & \multirow{2}{*}{$\begin{array}{c}\begin{array}{c}\text { Standardized } \\
\text { Coefficients }\end{array} \\
\text { Beta }\end{array}$} & \multirow[t]{2}{*}{$\mathrm{t}$} & \multirow[t]{2}{*}{ Sig. } \\
\hline & & B & Std. Error & & & \\
\hline \multirow{2}{*}{1} & (Constant) & 10.792 & 2.804 & & 3.849 & .000 \\
\hline & Kompensasi (X2) & .731 & .072 & .799 & 10.109 & .000 \\
\hline \multicolumn{7}{|c|}{ a. Dependent Variable: Produktivitas Karyawan (Y) } \\
\hline
\end{tabular}

Berdasarkan hasil perhitungan regresi pada tabel di atas, maka dapat diperoleh persamaan regresi $\mathrm{Y}=10,792+0,731 \mathrm{X}_{2}$. Dari persamaan di atas maka dapat disimpulkan sebagai berikut:

1. Nilai konstanta sebesar 10,792 diartikan bahwa jika variabel kompensasi $\left(\mathrm{X}_{2}\right)$ tidak ada, maka telah terdapat nilai produktivitas karyawan $(\mathrm{Y})$ sebesar 10,792 point.

2. Nilai koefisien regresi kompensasi $\left(\mathrm{X}_{2}\right)$ sebesar 0,731 diartikan apabila konstanta tetap dan tidak ada perubahan pada variabel motivasi $\left(\mathrm{X}_{1}\right)$, maka setiap perubahan 1 unit pada variabel kompensasi $\left(\mathrm{X}_{2}\right)$ akan mengakibatkan terjadinya perubahan pada produktivitas karyawan (Y) sebesar 0,731 point 


\section{Regresi Linier Berganda}

Tabel 14. Hasil Pengujian Regresi Berganda Variabel Motivasi $\left(\mathrm{X}_{1}\right)$ dan Kompensasi $\left(\mathrm{X}_{2}\right)$ Terhadap Produktivitas karyawan $(\mathrm{Y})$

\begin{tabular}{|c|c|c|c|c|c|c|}
\hline \multicolumn{7}{|c|}{ Coefficients ${ }^{a}$} \\
\hline & \multirow{2}{*}{ Model } & \multicolumn{2}{|c|}{$\begin{array}{l}\text { Unstandardized } \\
\text { Coefficients }\end{array}$} & \multirow{2}{*}{$\begin{array}{c}\begin{array}{c}\text { Standardized } \\
\text { Coefficients }\end{array} \\
\text { Beta }\end{array}$} & \multirow{2}{*}{$\mathrm{t}$} & \multirow{2}{*}{ Sig. } \\
\hline & & $\mathrm{B}$ & Std. Error & & & \\
\hline \multirow{3}{*}{1} & (Constant) & 5.828 & 2.831 & & 2.059 & .044 \\
\hline & Motivasi (X1) & .301 & .078 & .328 & 3.849 & .000 \\
\hline & Kompensasi (X2) & .564 & .078 & .617 & 7.227 & .000 \\
\hline
\end{tabular}

Sumber : Data diolah (2020)

Berdasarkan hasil analisis perhitungan regresi pada tabel di atas, maka dapat diperoleh persamaan regresi $\mathrm{Y}=5,828+0,301 \mathrm{X}_{1}+0,564 \mathrm{X}_{2}$. Dari persamaan di atas maka dapat disimpulkan sebagai berikut:

1. Nilai konstanta sebesar 5,828 diartikan bahwa jika variabel motivasi $\left(\mathrm{X}_{1}\right)$ dan kompensasi $\left(\mathrm{X}_{2}\right)$ tidak ada maka telah terdapat nilai produktivitas karyawan $(\mathrm{Y})$ sebesar 5,828 point.

2. Nilai motivasi $\left(X_{1}\right)$ 0,301 diartikan apabila konstanta tetap dan tidak ada perubahan pada variabel kompensasi $\left(\mathrm{X}_{2}\right)$, maka setiap perubahan 1 unit pada variabel motivasi $\left(\mathrm{X}_{1}\right)$ akan mengakibatkan terjadinya perubahan pada produktivitas karyawan (Y) sebesar 0,031 point.

3. Nilai kompensasi $\left(\mathrm{X}_{2}\right)$ 0,564 diartikan apabila konstanta tetap dan tidak ada perubahan pada variabel motivasi $\left(\mathrm{X}_{1}\right)$, maka setiap perubahan 1 unit pada variabel kompensasi $\left(\mathrm{X}_{2}\right)$ akan mengakibatkan terjadinya perubahan pada produktivitas karyawan $(\mathrm{Y})$ sebesar 0,564 point.

\section{Analisis Koefisien Korelasi (r)}

Tabel 15. Hasil Analisis Koefisien Korelasi Secara Simultan Antara Motivasi $\left(X_{1}\right)$ dan Kompensasi $\left(\mathrm{X}_{2}\right)$ Terhadap Produktivitas karyawan $(\mathrm{Y})$

\begin{tabular}{|l|c|c|c|c|}
\hline \multicolumn{5}{|c|}{ Model Summary } \\
\hline Model & $\mathrm{R}$ & R Square & $\begin{array}{c}\text { Adjusted R } \\
\text { Square }\end{array}$ & $\begin{array}{c}\text { Std. Error of the } \\
\text { Estimate }\end{array}$ \\
\hline 1 & $.844^{\mathrm{a}}$ & .713 & .703 & 1.92101 \\
\hline \multicolumn{4}{|c|}{ a. Predictors: (Constant), Kompensasi (X2), Motivasi (X1) } \\
Sumber : Data diolah (2020)
\end{tabular}

Berdasarkan pada hasil pengujian pada tabel di atas, diperoleh nilai $R$ (koefisien korelasi) sebesar 0,844 artinya variabel motivasi $\left(\mathrm{X}_{1}\right)$ dan kompensasi $\left(\mathrm{X}_{2}\right)$ mempunyai tingkat hubungan yang sangat kuat terhadap produktivitas karyawan (Y).

\section{Analisis Koefisien Determinasi (R Square)}

Tabel 16. Hasil Analisis Koefisien Determinasi Secara Simultan Antara Variabel Motivasi $\left(\mathrm{X}_{1}\right)$ dan Kompensasi $\left(\mathrm{X}_{2}\right)$ Terhadap Produktivitas karyawan ( $\mathrm{Y}$ )

\begin{tabular}{|l|c|r|c|c|}
\hline \multicolumn{5}{|c|}{ Model Summary } \\
\hline Model & $\mathrm{R}$ & $\begin{array}{c}\mathrm{R} \\
\text { Square }\end{array}$ & $\begin{array}{c}\text { Adjusted R } \\
\text { Square }\end{array}$ & $\begin{array}{c}\text { Std. Error of the } \\
\text { Estimate }\end{array}$ \\
\hline 1 & $.844^{\mathrm{a}}$ & .713 & .703 & 192.101 \\
\hline \multicolumn{5}{|c|}{ a. Predictors: (Constant), Kompensasi (X2), Motivasi (X1) } \\
\hline
\end{tabular}

Sumber : Data diolah (2020) 
Berdasarkan pada hasil pengujian pada tabel di atas, diperoleh nilai $R$-square sebesar 0,713 maka dapat disimpulkan bahwa variabel motivasi $\left(\mathrm{X}_{1}\right)$ dan kompensasi $\left(\mathrm{X}_{2}\right)$ berpengaruh terhadap variabel produktivitas karyawan $(\mathrm{Y})$ sebesar $71,3 \%$ sedangkan sisanya sebesar $28,7 \%$ dipengaruhi oleh faktor lain yang tidak dilakukan penelitian.

\section{Pengujian Hipotesis}

Tabel 17. Hasil Uji Hipotesis (Uji t) Variabel Motivasi $\left(\mathrm{X}_{1}\right)$

Terhadap Produktivitas karyawan (Y)

\begin{tabular}{|c|c|c|c|c|c|c|}
\hline \multicolumn{7}{|c|}{ Coefficientsa } \\
\hline & \multirow{2}{*}{ Model } & \multicolumn{2}{|c|}{$\begin{array}{l}\text { Unstandardized } \\
\text { Coefficients }\end{array}$} & \multirow{2}{*}{$\begin{array}{c}\begin{array}{c}\text { Standardized } \\
\text { Coefficients }\end{array} \\
\text { Beta }\end{array}$} & \multirow[t]{2}{*}{$\mathrm{t}$} & \multirow{2}{*}{ Sig. } \\
\hline & & B & Std. Error & & & \\
\hline \multirow{2}{*}{1} & (Constant) & 15.741 & 3.398 & & 4.633 & .000 \\
\hline & Motivasi (X1) & .614 & .089 & .670 & 6.880 & .000 \\
\hline
\end{tabular}

Sumber : Data diolah (2020)

Berdasarkan pada hasil pengujian pada tabel di atas diperoleh nilai $t_{\text {hitung }}>t_{\text {tabel }}$ atau $(6,880>2,002)$ Hal tersebut juga diperkuat dengan nilai $\rho$ value $<$ Sig.0,05 atau $(0,000<0,05)$. Dengan demikian maka $\mathrm{H}_{0}$ ditolak dan $\mathrm{H}_{1}$ diterima, hal ini menunjukkan bahwa terdapat pengaruh yang signifikan secara parsial antara motivasi terhadap produktivitas karyawan pada PT HADI PRIMA TEKNIK.

Tabel 18. Hasil Uji Hipotesis (Uji t) Variabel Kompensasi $\left(\mathrm{X}_{2}\right)$ Terhadap Produktivitas karyawan (Y)

\begin{tabular}{|c|c|c|c|c|c|c|}
\hline \multicolumn{7}{|c|}{ Coefficients $^{a}$} \\
\hline \multirow{2}{*}{\multicolumn{2}{|c|}{ Model }} & \multicolumn{2}{|c|}{$\begin{array}{l}\text { Unstandardized } \\
\text { Coefficients }\end{array}$} & \multirow{2}{*}{$\begin{array}{c}\begin{array}{c}\text { Standardized } \\
\text { Coefficients }\end{array} \\
\text { Beta } \\
\end{array}$} & \multirow[t]{2}{*}{$\mathrm{t}$} & \multirow{2}{*}{ Sig. } \\
\hline & & $\mathrm{B}$ & Std. Error & & & \\
\hline \multirow{2}{*}{1} & (Constant) & 10.792 & 2.804 & & 3.849 & .000 \\
\hline & Kompensasi (X2) & .731 & .072 & .799 & 10.109 & .000 \\
\hline
\end{tabular}

Sumber : Data diolah (2020)

Berdasarkan pada hasil pengujian pada tabel di atas diperoleh nilai $t_{\text {hitung }}>t_{\text {tabel }}$ atau $(10,109>2,002)$. Hal tersebut juga diperkuat dengan nilai $\rho$ value $<$ Sig.0,05 atau $0,000<$ $0,05)$. Dengan demikian maka $\mathrm{H}_{0}$ ditolak dan $\mathrm{H}_{2}$ diterima, hal ini menunjukkan bahwa terdapat pengaruh yang yang signifikan secara parsial antara kompensasi terhadap produktivitas karyawan pada PT HADI PRIMA TEKNIK.

Tabel 19. Hasil Hipotesis (Uji F) Secara Simultan Antara Motivasi ( $\left.X_{1}\right)$ dan Kompensasi $\left(\mathrm{X}_{2}\right)$ Terhadap Produktivitas karyawan $(\mathrm{Y})$

\begin{tabular}{|c|c|c|c|c|c|c|}
\hline \multicolumn{7}{|c|}{ ANOVAa } \\
\hline \multicolumn{2}{|c|}{ Model } & $\begin{array}{l}\text { Sum of } \\
\text { Squares }\end{array}$ & $\mathrm{df}$ & $\begin{array}{l}\text { Mean } \\
\text { Square }\end{array}$ & $\mathrm{F}$ & Sig. \\
\hline \multirow{3}{*}{1} & Regression & 521.655 & 2 & 260.827 & 70.680 & $.000^{\mathrm{b}}$ \\
\hline & Residual & 210.345 & 57 & 3.690 & & \\
\hline & Total & 732.000 & 59 & & & \\
\hline \multicolumn{7}{|c|}{ a. Dependent Variable: Produktivitas Karyawan (Y) } \\
\hline \multicolumn{7}{|c|}{ b. Predictors: (Constant), Kompensasi (X2), Motivasi (X1) } \\
\hline
\end{tabular}

Sumber : Data diolah (2020) 
Berdasarkan pada hasil pengujian pada tabel di atas diperoleh nilai $F_{\text {hitung }}>\mathrm{F}_{\text {tabel }}$ atau $(70,680>2,770)$, hal ini juga diperkuat dengan $\rho$ value $<$ Sig.0,05 atau $(0,000<0,05)$. Dengan demikian maka $\mathrm{H}_{0}$ ditolak dan $\mathrm{H}_{3}$ diterima, hal ini menunjukkan bahwa terdapat pengaruh yang signifikan secara simultan antara motivasi dan kompensasi terhadap produktivitas karyawan pada PT HADI PRIMA TEKNIK.

\section{Pembahasan Penelitian}

Berdasarkan hasil penelitian, menunjukkan bahwa motivasi $\left(\mathrm{X}_{1}\right)$ dan kompensasi $\left(\mathrm{X}_{2}\right)$ berpengaruh positif terhadap produktivitas karyawan dengan diperoleh persamaan regresi $Y$ $=5,828+0,301 \mathrm{X}_{1}+0,564 \mathrm{X}_{2}$. Nlai koefisien korelasi atau tingkat pengaruh antara variabel bebas dengan variabel terikat diperoleh sebesar 0,844 artinya memiliki memiliki pengaruh yang sangat kuat. Nilai koefisien determinasi atau kontribusi pengaruh secara simutan sebesar $71,3 \%$ sedangkan sisanya sebesar $28,7 \%$ dipengaruhi oleh faktor lain. Uji hipotesis diperoleh nilai $F_{\text {hitung }}>F_{\text {tabel }}$ atau $(70,680>2,770)$, hal tersebut juga diperkuat dengan probability significancy $0,000<0,05$. Dengan demikian $\mathrm{H}_{0}$ ditolak dan $\mathrm{H}_{3}$ diterima. Artinya terdapat pengaruh yang signifikan secara simultan antara motivasi dan kompensasi terhadap produktivitas karyawan pada PT HADI PRIMA TEKNIK.

\section{Kesimpulan}

Motivasi berpengaruh signifikan terhadap produktivitas karyawan dengan persamaan regresi $Y=15,741+0,614 \mathrm{X}_{1}$, nila koefisien korelasi sebesar 0,670 artinya kedua variabel memiliki tingkat pengaruh yang kuat dengan koefisien determinasi sebesar $0,449 \%$. Uji hipotesis diperoleh $\mathrm{t}$ hitung $>\mathrm{t}$ tabel atau $(6,880>2,002)$, hal ini diperkuat dengan probability signifikansi 0,000 <0,05, dengan demikian H0 ditolak dan H1 diterima artinya terdapat pengaruh signifikan antara motivasi terhadap produktivitas karyawan di PT. Utama Karya Niaga. Kompensasi berpengaruh signifikan terhadap produktivitas karyawan dengan persamaan regresi $\mathrm{Y}=10,792+0,731 \mathrm{X}_{2}$ nilai koefisien korelasi sebesar 0,6799 artinya kedua memiliki tingkat pengaruh yang kuat dengan koefisien determinasi sebesar $0,638 \%$. Uji hipotesis diperoleh $t_{\text {hitung }}>t_{\text {tabel }}$ atau $(10,109>2,002)$, hal ini diperkuat dengan probability signifikansi $0,000<0,05$, dengan demikian $\mathrm{H} 0$ ditolak dan $\mathrm{H} 2$ diterima artinya terdapat pengaruh signif-ikan antara kompensasi terhadap produktivitas karyawan (Y) di PT. Utama Karya Niaga. Motivasi dan kompensasi berpengaruh signifikan terhadap produktivitas karyawan dengan persamaan regresi $\mathrm{Y}=5,828+0,301 \mathrm{X}_{1}+0,564 \mathrm{X}_{2}$. Nilai koefisien korelasi diperoleh sebesar 0,844 artinya variabel bebas dengan varia-bel terikat memiliki tingkat pengaruh yang sangat kuat dengan koefisien determinasi atau pengaruh secara simultan sebesar $0,713 \%$ sedangkan sisanya sebesar $28,7 \%$ dipengaruhi faktor lain. Uji hipotesis diperoleh nilai $\mathrm{F}_{\text {hitung }}>\mathrm{F}_{\text {tabel }}$ atau $(70,680>2,770)$, hal tersebut juga diperkuat dengan probability signifikansi 0,000 $<0,05$. Dengan demikian HO ditolak dan H3 diterima. Artinya terdapat pengaruh signifikan secara simultan antara motivasi dan kompensasi terhadap produktivitas karyawan di PT HADI PRIMA TEKNIK.

\section{Daftar Pustaka}

Apriansyah, M. (2017). Hubungan Antara Kepemimpinan Dan Motivasi Kerja Terhadap Kinerja Pegawai Pada Kantor Kecamatan Ciputat Timur Kota Tangerang Selatan. Jurnal Jenius, $1(2), 44-58$.

Arikunto, S. (2014). Prosedur Penelitian Suatu Pendekatan Praktik. Jakarta : Rineka Cipta.

Batjo, Nurdin, \& Mahadin, S. (2018). Manajemen Sumber Daya Manusia. Cetakan Pertama. Aksara Timur: Makassar.

Dessler, G. (2015). Manajemen Sumber Daya Manusia. Jakarta: Salemba Empat.

Eka, P.D., Agusentoso, R., Suwanto, S., Aldy, H.L.N. and Gandung, M., 2020. PENGELOLAAN KEUANGAN PONPES DALAM RANGKA PENINGKATAN MASYARAKAT MANDIRI DI PANTI ASUHAN IKHWANIYAH CINTA YATIM DAN DHUAFA. Jurnal Pengabdian Dharma Laksana, 3(1),. 
Gandung, Muhammad, and Suwanto Suwanto. "Analisis Pengaruh Kompensasi Dan Gaya Kepemimpinan Terhadap Kinerja Karyawan Pada PT. Surya Rasa Loka Jaya Di Jakarta Barat." JENIUS (Jurnal Ilmiah Manajemen Sumber Daya Manusia) 3, no. 3 (2020): 236245.

Ghozali, I., \& Ratmono, D. (2017). Analisis Multivariat dan Ekonometrika dengan Eviews 10. Semarang: Badan Penerbit Universitas Diponegoro.

Hasibuan, M. S. P. (2018). Manajemen Sumber Daya Manusia. Cetakan ke-20. Jakarta: PT.Bumi Aksara.

Hermawati, R., Indriyani, S. (2019). Pengaruh Rekrutmen dan Kompensasi Terhadap Kinerja Karyawan Pada PT. Sinergi Inti Pelangi. Jurnal Jenius, 3(1), 24-41.

Kanto, M., Rappana, P. (2017). Filsafat Manajemen. Jakarta : Celebes Media Perkasa.

Komarudin. (2018). Pengaruh Pelatihan Dan Motivasi Terhadap Produktivitas Kerja Karyawan PT. Lion Mentari Airlines Bandara Soekarno Hatta Cengkareng. Jurnal Ilmiah Manajemen Forkamma, 1(2), 128-145.

Kusjono, G., Ratnasari, P. (2019). Pengaruh Motivasi Dan Kompensasi Terhadap Kinerja Karyawan Pada PT. Sumber Tenaga Lestari (Citylight Apartment) Tangerang Selatan. Jurnal Jenius. 2(2), 224-242.

Larasati, S. (2018). Manajemen Sumber Daya Manusia. Yogyakarta: Deepublish.

Maduningtias, L. (2019). Pengaruh Lingkungan kerja dan Budaya Organisasi Terhadap Produktivitas Karyawan Pada PT. L'Essential. Jurnal Jenius, 2(3), 394-400.

Mangkunegara, A. P. (2013). Manajemen Sumber Daya Manusia Perusahaan. Bandung: PT. Remaja Rosda Karya.

Marayasa, I. N., Faradila, A. (2019). Pengaruh Motivasi Dan Disiplin Kerja Terhadap Kinerja Karyawan PT. Bank Dinar Indonesia. Jurnal Ekonomi Efektif , 2(2), 110-122.

Marjuni, S. (2015). Manajemen Sumber Daya Manusia. Makassar: CV. Sah Media.

Masram, \& Mu'ah. (2015). Manajemen Sumber Daya Manusia. Bandung: Zifatama Publisher.

Paeno. (2018). Pengaruh Motivasi dan Disiplin Terhadap Produktivitas Pada PT. Agra Energi Indonesia. Jurnal Jenius, 1(3), 290-306.

Puspita, W. (2018). Manajemen Konflik: Suatu Pendekatan Psikologi, Komunikasi dan Pendidikan.Yogyakarta: Deepublish.

Santoso, S. (2015). Menguasai Statistik Multivariat. Jakarta : PT Elex Media Komputindo.

Sari, R. (2019). Pengaruh Kompensasi Terhadap Kinerja Karyawan Pada PT Perma Plasindo Jakarta. Jurnal Disrupsi Bisnis, 2(2), 48-62.

Sugiyono. (2016). Metode Penelitian Kuantitatif, Kualitatif dan R\&D. Bandung: PT Alfabet. . (2017). Metode Penelitian Kuantitatif, Kualitatif dan R\&D. Bandung: PT Alfabet.

Sunarsi, D. (2018). Pengaruh Motivasi dan Disiplin Terhadap Produktivitas Kerja Karyawan Pada PT. Nadi Suwarna Bumi. Jurnal Ilmiah semarak, 1(1), 66-82.

Supangat, . (2015). Statistika dalam Kajian Deskriftif, Inferensi dan Non parametrik. Edisi Pertama. Jakarta: Kencana Prenada Media Group.

Suryani, N. L., Hastono. (2020). Pengaruh Kompensasi dan Kepuasan Kerja Terhadap Kinerja Karyawan Pada PT. Mitra Agung Persada Di Jakarta. Jurnal Jenius, 3(3), 322-332.

Sutrisno, E . (2012). Manajemen Sumber Daya Manusia. Jakarta: Kencana.

Priehadi Dhasa eka n Suwanto. (2020), Audit Sumber Daya Manusia, Desanta Muliavisistama

Suwanto. (2020), Manajemen Sumber Daya Manusia , Desanta Muliavisistama.

Suwanto. (2020), Strategi Pemberdayaan potensi pemuda karang taruna, Desanta Muliavisistama

Suwanto, S. (2019). Pengaruh Disiplin Kerja Dan Motivasi Kerja Terhadap Kinerja Karyawan Pada Rumah Sakit Umum Tangerang Selatan. JENIUS (Jurnal Ilmiah Manajemen Sumber Daya Manusia), 3(1), 16-23. 
Suwanto, S., Eka, P. D., Juanda, A., Gandung, M., \& Kurniawan, P. (2020). Pengelolaan Kewirausahaan di Era 4g untuk Peningkatan Kesejahteraan di Desa Cicalengka Kecamatan Pagedangan Kabupaten Tangerang Banten. DEDIKASI PKM, 1(3), 103-108.

Suwanto, S., Eka, P. D., Agusentoso, R., Juanda, A., \& Kurniawan, P. (2020). MENGGALI POTENSI, MEMOTIVASI DAN MENGARAHKAN GENERASI MUDA MENYONGSONG DUNIA KERJA PADA PKBM CIPTA TUNAS KARYA CIPONDOH KOTA TANGERANG. Jurnal Pengabdian Dharma Laksana, 2(2), 132-136.

Suwanto, S. (2019). Pengaruh Gaya Kepemimpinan Dan Lingkungan Kerja Terhadap Kinerja Karyawan Unit Telesales Pada PT BFI Finance Indonesia TBK. Jurnal Ekonomi Efektif, $1(2)$.

Suwanto, S., \& Eka, P. D. (2020). Analysis Of Leadership Style Influence, Job Motivation, And Compensation Towards Teacher Satisfaction On The Foundation Of Al-Hasra Bojongsari. Depok City. International Journal of Advances in Social and Economics, 2(3).

Suwanto, S. (2020). Pengaruh Kepemimpinan Dan Motivasi Kerja Terhadap Kinerja Karyawan Pada Koperasi Bmt El-Raushan Tangerang. JENIUS Jurnal Ilmiah Manajemen Sumber Daya Manusia), 3(2), 156-165. 